\title{
The effects of a fogging system on the physiological status and rooting capacity of leafy cuttings of woody species
}

Mateja Štefančič · Dominik Vodnik •

Franci Štampar · Gregor Osterc

Published online: 13 June 2007

(C) Springer-Verlag 2007

\section{Erratum to: Trees}

\section{DOI 10.1007/s00468-006-0121-z}

Unfortunately, first names and surnames of the authors were interchanged. Instead of "Štefančič Mateja, Vodnik Dominik, Štampar Franci, Osterc Gregor", they should read: "Mateja Štefančič, Dominik Vodnik, Franci Štampar, Gregor Osterc'.

The online version of the original article can be found under doi:10.1007/s00468-006-0121-z.

M. Štefančič · D. Vodnik · F. Štampar · G. Osterc $(\bowtie)$

Biotechnical Faculty, Department of Agronomy,

University of Ljubljana, Jamnikarjeva 101,

1000 Ljubljana, Slovenia

e-mail: gregor.osterc@bf.uni-lj.si 